\title{
The Development of Deep and Short Sea Shipping Container Routes Departing from Italian Ports
}

\section{Razvoj obalnih i prekooceanskih pomorskih kontejnerskih ruta koje kreću iz talijanskih luka}

\author{
Marino Lupi \\ University of Pisa \\ Department of Civil and Industrial \\ Engineering and University Centre \\ of Logistic Systems \\ E-mail:marino.lupi@unipi.it
}

\author{
Antonio Pratelli \\ University of Pisa \\ Department of Civil and Industrial \\ Engineering and University Centre \\ of Logistic Systems \\ E-mail: antonio.pratelli@unipi.it
}

\author{
Luca Seminara \\ University of Pisa \\ University Centre of Logistic Systems \\ E-mail: luca.seminara77@gmail.com
}

\author{
Alessandro Farina \\ University of Pisa \\ Department of Civil and Industrial \\ Engineering and University Centre of \\ Logistic Systems \\ E-mail: alessandro.farina@unipi.it
}

\section{Summary}

In this paper, an analysis of the development of Deep Sea Shipping (DSS) and Short Sea Shipping (SSS) container routes calling at Italian ports, is carried out. Data about DSS routes have been collected in the years: 2011, 2014, 2018 and 2019, while data about SSS services have been collected in 2010 and 2018. Italian ports have been classified as follows: Ligurian multi-port gateway cluster, formed by Leghorn, La Spezia, Genoa, Savona/Vado Ligure; Northern Adriatic multi-port gateway cluster, made up of Ancona, Ravenna, Venice and Trieste; Campanian multi-port gateway cluster, composed of Naples and Salerno; hub ports, i.e. Gioia Tauro, Cagliari (only until 2018) and Taranto (only until 2014). The most important gateway cluster, for both DSS and SSS services, is the Ligurian one, which includes Genoa, the major Italian container gateway port. Genoa has shown an almost constant increase in container traffic in the time period analyzed. Italian hub ports are also an important group, but they have registered a negative trend in the years under analysis. DSS routes, to Far East and the American Continent, usually call at the Ligurian ports and the hub port of Gioia Tauro. Northern Adriatic ports are crossed by only a few DSS routes, but they are crossed by a large number of SSS routes, especially feeder ones, with transshipment mainly in the hub ports of Gioia Tauro, Marsaxlokk, Piraeus and Port Said. The evolution of DSS services shows clearly the effects of naval gigantism phenomenon: the number of DSS services has decreased, but the total and, especially, the average DWT have increased. As regards SSS routes, also their frequencies have decreased, but their length and, in particular, the number of ports called, have increased: this choice is performed by container operators in order to increase the ships 'load factor'.

\section{Sažetak}

U ovome članku iznosi se analiza razvoja prekooceanskih (DSS) i obalnih (SSS) kontejnerskih ruta koje dodiruju talijanske luke. Podaci u vezi s prekooceanskim lukama prikupljeni su za godine 2011., 2014., 2018. i 2019., dok su podaci za obalnu službu prikupljeni za 2010. i 2018. Talijanske luke klasificirane su kako slijedi: ligurski lučki klaster koji čine Livorno, La Spezia, Đenova, Savona/Vado Ligure; sjeverojadranski lučki klaster koji čine Ancona, Ravena, Venecija i Trst; kampanijski lučki klaster koji čine Napulj i Salerno te središnje luke, tj. Gioia Tauro, Cagliari (samo do 2018.) i Taranto (samo do 2014.). Najvažniji lučki klaster i za prekooceanske iza obalne kontejnerske rute jest onaj ligurski koji uključujeĐenovu, najvažniji talijanski lučki grad. Đenova je pokazala gotovo stalan porast u kontejnerskom prometu u analiziranom razdoblju. Talijanske ključne luke također čine važnu skupinu, ali su zabilježile negativan trend u razmotrenim godinama. Prekooceanske rute do Bliskog istoka i američkog kontinenta obično vode prema ligurskim lukama i središnjoj luci Gioa Tauro. Sjeverojadranske luke presječene su samo nekim prekooceanskim, ali i brojnim obalnim rutama, posebno onima opskrbe s pretovarom, uglavnom u gradskim lukama Gioa Tauro, Marsaxlokk, Piraeus i Port Said. Evolucija prekooceanskih ruta jasno pokazuje učinke fenomena pomorskoga gigantizma: broj prekooceanskih ruta smanjen je, ali ukupan i posebice prosječan iznos brutoregistarske tonaže porastao je. Što se tiče obalnih ruta, njihova je učestalost također smanjena, aliduljinai posebno brojluka u koje se dolazi povećanje:ovaj izborčine kontejnerski izvršitelji kako bi time povećali brodski „,čimbenik ukrcaja”.
DOI 10.17818/NM/2021/2.4

UDK 629.544:656.615(450)

Review / Pregledni rad

Paper accepted / Rukopis primljen: 16. 5. 2020.

\section{KEY WORDS \\ Italian ports \\ deep seashipping \\ DSS \\ short sea shipping \\ SSS \\ container routes \\ container traffic}

\section{KLJUČNE RIJEČI \\ talijanske luke prekooceanska ruta \\ DSS \\ obalna ruta \\ SSS \\ kontejnerske rute \\ kontejnerski promet}

\section{INTRODUCTION / Uvod}

A port could be seen as the connection point between maritime and inland transport: briefly, a port is an "access gate" to its hinterland. The hinterland of a port is made up of: the "fundamental hinterland" and the "competitive hinterland"
(Rodrigue [1]). The fundamental hinterland is usually formed by regions which are the closest to the port, and it consists of the areas which mainly (or exclusively) belong to the port market. The "competitive hinterland" is the external part of the port 
hinterland, and it is overlapped with the hinterland of other ports.

The development of inland ports (dry ports), inland terminals, which are well connected with the port (by railway or inland waterway corridors) enlarges port hinterlands and determines the last phase of the development of a port: the so called 'port regionalization' (Notteboom and Rodrigue [2]). Therefore, nowadays, a port hinterland may consist also of areas which are not geographically close to the port ('discontinuous hinterland') and which are linked with the given port by railway or inland waterway efficient corridors.

The high performance of inland transport and the availability of efficient and well located inland terminals acquire a strategic role in the development of "island formations" within the hinterland of other ports (Monios and Wilmsmeier [3]). An example of this phenomenon is the Padan Plain in Italy, which is in the natural hinterland of the Italian northern Ligurian and Adriatic ports and has become, although only partially, an "island formation" of northern European ports. This has occurred because of the establishment of high performance rail connections to/from northern European ports and of a set of well located inland terminals (Lupi et al. [4]). Van Klink and Van Der Berg, [5], see particularly fig. 3, show that the "island formation" in the Padan Plain is not a recent phenomenon (sea about this also Ferrari et al. [6], p. 384). The Padan Plain is the Italian most productive area.

The extension of the hinterland of a port depends not only on the port inland connections but also on the port transit times. An analysis of transit times at Italian container ports is performed in Baldassarra et al. [7].

Notteboom [8] has grouped European ports in 'multi-port' gateway regions. Again Notteboom [9] has suggested the following grouping for the Italian ports:

- Ligurian multi-port gateway system: composed of the ports of: Leghorn, La Spezia, Genoa and Savona / Vado Ligure.

- Northern Adriatic multi-port gateway system: composed of the Italian ports of Ancona, Ravenna, Venice and Trieste and of the non Italian ports of Koper (Slovenia) and Rijeka (Croatia).

- Campanian gateway system: composed of the ports of Naples and Salerno, both located on the southern Tyrrhenian Sea.

- Italian hub ports system: it used to consist of Gioia Tauro, Taranto e Cagliari, but, currently, only Gioia Tauro is operational; instead, Taranto container terminal is closed since 2017, while Cagliari is currently crossed only by SSS routes. Gioia Tauro is almost exclusively a transhipment port ('nearly pure hub port').

In addition, other Italian ports, not belonging to any of the aforementioned clusters, are crossed by container routes, mainly SSS ones: Civitavecchia, Bari, Palermo, Trapani and Catania. Civitavecchia is located in the Latium region, close to Rome; Bari is located on the southern Adriatic Sea; the last three ports are in Sicily.

In this paper, an overview of Deep Sea Shipping (DSS) and Short Sea Shipping (SSS) container routes from Italian ports is presented. The paper is organized as follows. In section 2, an overview of the container traffic in Italy is carried out. In section 3, the evolution of DSS container services from Italian ports, from 2011 to 2019, is presented. In section 4, the evolution of SSS container services, from Italian ports, from 2010 to 2018, is described. In section 5 , DSS and SSS services are considered simultaneously in order to assess the global importance of each Italian port and port cluster in container Italian routes. Conclusions follow.

\section{OVERVIEW OF CONTAINER THROUGHPUT AT ITALIAN PORTS / Pregled obrtaja kontejnerskog tereta u talijanskim lukama}

In this section, the overall container throughput at Italian ports, from 2007 (the pre-crisis year) to 2018 is analyzed.

In table 1, the container traffic time series at Italian ports is shown. In table 2, the average growth rate at Italian ports is reported: from 2007 to 2018 and from 2010 to 2018.

In the table 1, ports are grouped as described in the introduction. On the row 'Total Ligurian gateway', the sum of the container throughput of Ligurian ports is reported: that is, the sum of the throughputs of Leghorn, La Spezia, Genoa and Savona / Vado Ligure. The same applies to the rows: 'Total Adriatic gateway,, 'Total Campanian gateway', 'Total hub ports' and 'Total other ports.' 'Total Italy' is the sum of the container throughput of all Italian ports.

It can be seen that the overall container throughput of Italian ports has not increased in the years under consideration. Indeed, after 2007, the pre-crisis year, the container throughput has shown a sharp decrease, and the pre-crisis value has been recovered only in 2017. However, it can be observed that, if only gateway traffic is considered, the container throughput has increased. Gateway traffic is more important than that of hub ports in terms of added value, as shown, for example, in Buonfanti [10].

The global trend of traffic at Italian ports is due to: the decrease of hub ports on one hand, and the increase of Ligurian and northern Adriatic gateway ports on the other.

Italian hub ports have decreased with an average rate of $-5.3 \%$ from 2007 to 2018 . Indeed, the throughput of Gioia Tauro in 2018 has been about 2.3 million TEUs, which is very far from the 2007 and 2008 throughput, equal to 3.4 million TEUs: Gioia Tauro has shown a sharp decrease, by over 19\%, from 2010 to 2011; after that year, the throughput of Gioia Tauro has shown a fluctuating trend, and the throughput in 2018 is almost the same to that in 2011. Moreover, the other two Italian hub ports, Cagliari and Taranto, are no longer in operation as transhipment ports: Taranto container terminal does not register any container traffic since 2015, while, since 2019, Cagliari is crossed by only SSS routes.

The decrease of Italian hub ports is partially due to the competition performed by the other Mediterranean hub ports, especially: Marsaxlokk (Malta), Piraeus and Port Said. Piraeus has increased from 1.4 million TEUs in 2007 to 4.1 in 2017, while Marsaxlokk (Malta) has increased from 1.9 to 3.2 million TEUs in the same years (source: Assoporti [12]). Instead Port Said has shown a fluctuating trend: its throughput has increased from 1.5 million TEUs in 2007 to 4.3 in 2011, but after it has decreased to 3 million TEUs in 2016. Port Said and Piraeus are transhipment ports at most for routes to/from Asia, while Malta is a transhipment port also for routes to/from the American continent. 
Table 1 Container throughput at Italian ports from 2007 to 2018

Tablica 1. Obrtaj kontejnerskog tereta u talijanskim lukama od 2007. do 2018.

\begin{tabular}{|c|c|c|c|c|c|c|c|c|c|c|c|c|}
\hline PORTS & 2007 & 2008 & 2009 & 2010 & 2011 & 2012 & 2013 & 2014 & 2015 & 2016 & 2017 & 2018 \\
\hline Genoa & 1855.0 & 1766.6 & 1533.6 & 1758.9 & 1847.1 & 2064.8 & 1988.0 & 2172.9 & 2242.9 & 2297.9 & 2622.2 & 2609.1 \\
\hline La Spezia & 1187.0 & 1246.1 & 1046.1 & 1285.2 & 1307.3 & 1247.2 & 1300.4 & 1303.0 & 1300.4 & 1272.4 & 1473.6 & 1485.6 \\
\hline Leghorn & 745.6 & 778.9 & 592.1 & 628.8 & 637.8 & 549.0 & 559.2 & 577.5 & 80.9 & 0.5 & 734.1 & 748.0 \\
\hline Vado Ligure & 242.7 & 252.8 & 196.3 & 196.4 & 170.4 & 75.3 & 77.9 & 85.3 & 98.0 & 55.0 & 44.1 & 65.3 \\
\hline Total Ligurian & 4032.6 & 4049.1 & 3374.3 & 3877.1 & 3968.1 & 3936.4 & 3925.9 & 4139.1 & 4422.3 & 4458.6 & 4926.5 & 4966.0 \\
\hline Ancona & 87.2 & 119.1 & 105.5 & 110.4 & 120.7 & 142.2 & 152.4 & 168.9 & 178.5 & 185.8 & 168.6 & 159.1 \\
\hline Ravenna & 206.8 & 214.3 & 185.0 & 183.6 & 215.3 & 208.2 & 226.7 & 222.5 & 244.8 & 234.5 & 223.4 & 216. \\
\hline Venice & 329.5 & 379.1 & 369.5 & 393.9 & 458.4 & 429.9 & 446.4 & 456.1 & 560.3 & 605.9 & 611.4 & 632.3 \\
\hline Trieste & 265.9 & 335.9 & 277.0 & 281.6 & 393.2 & 408.0 & 458.6 & 506.0 & 501.2 & 486.5 & 616.2 & 725.4 \\
\hline Total Adr & 889.4 & 1048.4 & 937 & 969.5 & 1187.6 & 1188.3 & 1284.1 & 1353.5 & 84.8 & 1512.7 & 1619.6 & 1733.1 \\
\hline Naples & 460.8 & 481.5 & 515.9 & 534.7 & 526.8 & 546.8 & 477.0 & 431.7 & 438.3 & 483.5 & 509.9 & 583.4 \\
\hline Salerno & 385.3 & 330.4 & 269.3 & 234.8 & 235.2 & 208.6 & 263.4 & 320.0 & 359. & 388.6 & 54.7 & 453 \\
\hline Total Campar & 846.1 & 811.9 & 785.2 & 769.5 & 762 & 755.4 & 740.4 & 751.7 & 797.6 & 872.1 & 964.6 & 1036.6 \\
\hline Gioia Tauro & 3445.3 & 3467.8 & 2857.4 & 2852.3 & 2305.0 & 2721.1 & 3094.3 & 2969.8 & 2546.8 & 2797.1 & 2448.6 & 2328.3 \\
\hline Cagliari & 547.3 & 307.5 & 737.0 & 629.3 & 603.2 & 627.6 & 702.1 & 717.0 & 748.6 & 723.0 & 463.9 & 288 \\
\hline Taranto & 755.9 & 786.7 & 741.9 & 581.9 & 604.4 & 263.5 & 197.3 & 148.5 & - & 0.4 & - & - \\
\hline Total Italia & 4748.5 & 4562 & 4336.3 & 4063.5 & 3512.6 & 3612.2 & 3993.7 & 3835.3 & 3295.4 & 3520.5 & 2912.5 & 2617.1 \\
\hline Civitavecchia & 31.1 & 25.2 & 28.3 & 41.5 & 38.2 & 51.0 & 54.0 & 64.4 & 66.7 & 74.2 & 94.4 & 108. \\
\hline Bari & 0.06 & 0.1 & 0.06 & 0.7 & 11.1 & 29.4 & 31.3 & 35.9 & 60. & 71.6 & 68.7 & 68 \\
\hline Catania & 22.5 & 18.0 & 21.8 & 20.6 & 17.7 & 22.1 & 30.3 & 33.2 & 49 & 49.2 & 50.1 & 59 \\
\hline Palermo & 31.8 & 32.7 & 30.1 & 33.5 & 28.6 & 22.8 & 20.6 & 14.3 & 12. & 12.2 & 13.3 & 16 \\
\hline Total oth & 85.5 & 76.0 & 80.3 & 96.3 & 95.6 & 125.3 & 136.2 & 147.8 & 89.3 & 207.2 & 226.5 & 252.5 \\
\hline Total Italian gateway ports & 5768.1 & 5909.4 & 5096.5 & 5616,1 & 5917.7 & 5880.1 & 5950.4 & 6244.3 & 6704.7 & 6843.4 & 7510.7 & 7735.7 \\
\hline Total Italian ports & 10609.1 & 10549.9 & 9514.7 & 9778.0 & 9526.8 & 9618.7 & 10082.0 & 10224.7 & 10190.6 & 10573.4 & 10651.4 & 10606.2 \\
\hline Koper (SLO) & 305.6 & 353.9 & 343.2 & 476.7 & 589.3 & 570.7 & 600.4 & 674.0 & 790.7 & 844.8 & 911.5 & 988.5 \\
\hline Rijeka (HR) & 145.0 & 168.8 & 130.7 & 137.0 & 150.7 & 171.9 & 169.9 & 192.0 & 200.1 & 214.3 & 250.0 & 260 \\
\hline $\begin{array}{l}\text { Total non Italian Adriat } \\
\text { gateway }\end{array}$ & 450.7 & 522.6 & 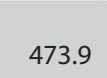 & 0 & 740.0 & 1 & 10.7 & 866. & 990 & 1059.1 & 1161.5 & 124 \\
\hline $\begin{array}{l}\text { Total Adriatic gatewa } \\
\text { Italian + non Italian }\end{array}$ & 1252.9 & 1451.9 & 1305.4 & 1472.9 & 1806.9 & 1788.8 & 1902.2 & 2000.8 & 2356.2 & 2505.4 & 2607.7 & 2982.0 \\
\hline
\end{tabular}

Source: Assoporti [11],[12]

The most important Italian port cluster is the Ligurian one: it shows the highest container throughput, but, globally, it shows a much lower average growth rate, i.e. $+1.9 \%$ from 2007 to 2018, respect to the total (Italian + non Italian) Adriatic gateway system, whose average growth rate is equal, in the same time interval, to $8.2 \%$. Genoa is the main Italian gateway port: it has increased the throughput by $3.1 \%$ from 2007 to 2018, and by over 5\% from 2010 to 2018 . The other main Ligurian ports are La Spezia and Leghorn: La Spezia has shown an almost constant increase and, currently, it is the second gateway container Italian port; Leghorn has shown fluctuations in the years under consideration and the throughput in $\mathbf{2 0 1 8}$ has almost been the same as in 2007. Ligurian ports, thanks to their position, are crossed by the main DSS container routes, directed to all world areas as it will described in the following section. These routes cross also the Italian hub port of Gioia Tauro and the Campanian gateway ports. Instead Northern Adriatic ports are crossed by only a few DSS routes, to Far East, but they are crossed by several SSS services. However, they show the highest growth rate among Italian port clusters, equal to $+6.3 \%$ from 2007 to 2018 . But non Italian northern Adriatic ports, i.e. Koper (Slovenia) and Rijeka (Croatia) show a higher average growth rate: $+9.7 \%$ from 2007 to 2018. Koper is the most important port as to traffic, but also Trieste, Venice and Rijeka are important.

Table 2 Growth rates of container throughput at Italian ports from 2007 to 2018 Tablica 2. Stope rasta kontejnerskog prometa u talijanskim lukama od 2007. do 2018.

\begin{tabular}{|l|c|c|} 
& $\begin{array}{c}\text { Average growth rate } \\
2007-2018\end{array}$ & $\begin{array}{c}\text { Average growth rate } \\
2010-2018\end{array}$ \\
\hline Total Ligurian gateway & $1.9 \%$ & $3.1 \%$ \\
\hline Total Italian Adriatic gateway & $6.3 \%$ & $7.5 \%$ \\
\hline Total Campanian gateway & $1.9 \%$ & $3.8 \%$ \\
\hline Total Italian hub ports & $-5.3 \%$ & $-5.4 \%$ \\
\hline Total Italian gateway ports & $2.7 \%$ & $4.1 \%$ \\
\hline Total Italian ports & $0.00 \%$ & $1.02 \%$ \\
\hline Total non Italian Adriatic gateway & $9.7 \%$ & $9.3 \%$ \\
\hline Total Adriatic gateway: Italian + non Italian & $8.2 \%$ & $9.2 \%$ \\
\hline
\end{tabular}




\section{EVOLUTION OF DSS CONTAINER ROUTES DEPARTING FROM ITALIAN PORTS / Razvoj prekooceanskih $i$ kontejnerskih ruta koje kreću iz talijanskih luka}

The evolution of DSS container routes from 2011 to 2019 has been studied. Data have been collected in: January 2011, August 2014, March 2018 and October 2019. This research has been performed through a collection of data from:

- two journals: 'L'Avvisatore Marittimo' [13], as regards 2011, 2018 and 2019 data, and 'Il Messaggero Marittimo' [14] for 2014 data. In these journals the list of ship departures from each Italian port is reported;

- Marinetraffic website [15], which provides, day by day, for each ship: the exact position and the total ship capacity in terms of DWT (Dead Weight Tonnage);

- the major global shipping companies websites.

\subsection{Analysis of DSS container routes departing from Italian ports in 2019 / Analiza prekooceanskih i kontejnerskih ruta koje kreću iz talijanskih luka u 2019.}

Table 3 shows DSS container services departing from Italian ports in the year 2019 (data refer to October 2019). The data are reported separately for the four clusters mentioned above. The same information, for the years 2018, 2014 and 2011, is reported respectively in Lupi et al. [16],[17],[18]. In Table 3, for each port, is shown: the number of services per month, the total and the average DWT.

The total DWT for a port is equal to the sum of the capacity (expressed in DWT) of all ships departing from the given port. The average DWT for a port is equal to the total DWT divided by the number of ships departing from the port. The number of ships from a port cluster is the number of ships leaving at least one port of the cluster. For example, if a ship leaves both Genoa and La Spezia, it is counted once.

Genoa is the major Italian port: it shows the maximum number of services per month and the maximum total DWT.

Taking into account the four groupings of Italian ports, exposed in the introduction, the Ligurian port cluster is by far the most important in Italy, both in terms of services per month and total DWT. The average DWT values are higher for the Italian northern Adriatic gateway system, however, currently, only 7 ships per month depart from Italian northern Adriatic ports: all these ships depart from the port of Trieste; only one DSS ship departs from Venice (which calls at Trieste too), while only SSS routes depart from Ravenna and Ancona. 22 DSS ships per month depart from Campanian gateway ports, while 27 DSS ships per month depart from the hub port of Gioia Tauro. However, ships departing from Campanian ports are not very large, while ships departing from Gioia Tauro have an average DWT of about 111 thousand tons.

Table 3 A synthesis on the DSS container services from Italian ports to each world region, in terms of: number of services by month and total and average DWT. Data refer to October 2019

Tablica 3. Sinteza DSS kontejnerskih usluga iz talijanskih luka do pojedine regije u svijetu, izražena po mjesecima te ukupnoj i prosječnoj bruto registarskoj tonaži. Podaci se odnose na listopad 2019.

\begin{tabular}{|c|c|c|c|c|c|c|c|c|c|c|c|c|c|}
\hline 2019 & 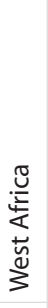 & 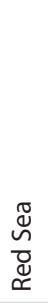 & 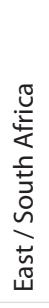 & 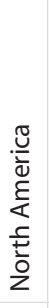 &  & 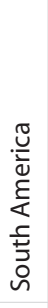 &  & $\begin{array}{l}\frac{4}{5} \\
0 \\
\frac{1}{0} \\
\frac{0}{0} \\
\frac{0}{0} \\
0 \\
\frac{0}{2} \\
\frac{0}{0} \\
\frac{0}{0} \\
\frac{0}{0} \\
\end{array}$ & 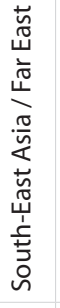 & 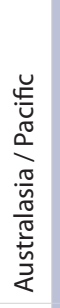 &  & 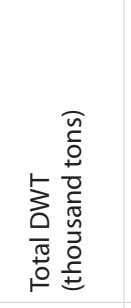 &  \\
\hline Genoa & 4 & 25 & 5 & 15 & 20 & 10 & 6 & 24 & 31 & 2 & 81 & 7972.52 & 98.43 \\
\hline La Spezia & 1 & 11 & 3 & 13 & 9 & 3 & 2 & 10 & 24 & 4 & 43 & 4251.97 & 98.88 \\
\hline Leghorn & 1 & 0 & 1 & 15 & 23 & 8 & 12 & 0 & 1 & 1 & 41 & 2760.18 & 67.32 \\
\hline Vado Ligure & 0 & 0 & 0 & 0 & 5 & 0 & 5 & 0 & 0 & 0 & 5 & 172.88 & 34.58 \\
\hline Tot. Ligurian gate & 4 & 25 & 7 & 26 & 29 & 12 & 12 & 24 & 33 & 5 & 103 & 8956.28 & 86.95 \\
\hline Venice & 0 & 1 & 0 & 0 & 0 & 0 & 0 & 0 & 1 & 0 & 1 & 63.11 & 63.11 \\
\hline Trieste & 0 & 2 & 0 & 0 & 0 & 0 & 0 & 5 & 7 & 0 & 7 & 1011.04 & 144.43 \\
\hline Tot. Italian Adriatic gateway & 0 & 2 & 0 & 0 & 0 & 0 & 0 & 5 & 7 & 0 & 7 & 1011.04 & 144.43 \\
\hline Naples & 0 & 4 & 3 & 4 & 7 & 2 & 4 & 5 & 4 & 0 & 14 & 933.04 & 66.65 \\
\hline Salerno & 0 & 0 & 0 & 10 & 4 & 0 & 4 & 0 & 0 & 0 & 13 & 502.18 & 38.63 \\
\hline Tot. Campanian gateway & 0 & 4 & 3 & 12 & 7 & 2 & 4 & 5 & 4 & 0 & 22 & 1195.25 & 54.33 \\
\hline Gioia Tauro & 1 & 5 & 3 & 7 & 5 & 7 & 2 & 8 & 11 & 3 & 27 & 3006.59 & 111.36 \\
\hline Tot. hub ports & 1 & 5 & 3 & 7 & 5 & 7 & 2 & 8 & 11 & 3 & 27 & 3006.59 & 111.36 \\
\hline Civitavecchia & 0 & 0 & 0 & 0 & 6 & 1 & 6 & 1 & 2 & 0 & 7 & 284.74 & 40.68 \\
\hline Palermo & 0 & 1 & 0 & 0 & 0 & 0 & 0 & 1 & 0 & 0 & 1 & 44.57 & 44.57 \\
\hline Tot. other port & 0 & 1 & 0 & 0 & 6 & 1 & 6 & 2 & 2 & 0 & 8 & 329.31 & 41.16 \\
\hline TOTAL ITALY & 5 & 31 & 7 & 26 & 30 & 13 & 13 & 37 & 52 & 5 & 121 & 11683.21 & 96.56 \\
\hline
\end{tabular}

Sources: L'Avvisatore Marittimo [13], Marinetraffic [15] and shipping companies websites [19]. 
Table $4 \mathrm{~N}^{\circ}$ of services and total and average DWT of services from Italian ports to each world region. Data refer to October 2019 Tablica 4. Broj usluga, ukupna i prosječna bruto registarska tonaža iz talijanskih luka do pojedine regije. Podaci se odnose na listopad 2019.

\begin{tabular}{|l|r|r|r|}
\hline World region & $\begin{array}{c}n^{\circ} \text { services / } \\
\text { month }\end{array}$ & $\begin{array}{c}\text { Total DWT } \\
\text { (thousand tons) }\end{array}$ & $\begin{array}{c}\text { Average DWT } \\
\text { (thousand tons) }\end{array}$ \\
\hline West Africa & 5 & 213.60 & 42.72 \\
\hline Red Sea & 31 & 3172.85 & 102.35 \\
\hline East / South Africa & 7 & 567.49 & 81.07 \\
\hline North America (Atlantic) & 26 & 1665.68 & 64.06 \\
\hline Central America (Atlantic) & 30 & 2174.91 & 72.50 \\
\hline South America (Atlantic + Pacific) & 13 & 1365.70 & 105.05 \\
\hline America / Pacific (North + Central) & 13 & 781.58 & 60.12 \\
\hline Arabian / Persian Gulf & 37 & 4548.88 & 122.94 \\
\hline South-East Asia / Far East & 52 & 6917.56 & 133.03 \\
\hline Australasia / Pacific & 5 & 400.33 & 80.07 \\
\hline Total Italy & 121 & 11683.21 & 96.56 \\
\hline
\end{tabular}

Sources: L'Avvisatore Marittimo [13], Marinetraffic [15] and shipping companies websites [19].

In the analysis of DSS routes, the classification proposed by 'L'Avvisatore Marittimo' has been adopted: West Africa, Red Sea, East and South Africa, North America (Atlantic coast), Central America (Atlantic coast), South America (Atlantic and Pacific coast), America/Pacific (i.e. the Pacific coast of North and Central America), Arabian/Persian Gulf, South-East Asia/Far East, Australasia/Pacific. DSS services from Italian ports to each world region have been summarized in table 4. 'Total DWT' means 'the sum of the DWT of all ships departing from Italian ports and directed to the world region indicated in the row'.

The most important world region, as far as the number of services is concerned, is South-East Asia/Far East; this is due to the economic and demographic relevance of the countries belonging to this region: India ('L'Avvisatore Marittimo' classifies India as belonging to South-East Asia), China, Japan, Korea, Taiwan, Malaysia, Singapore. The main container ports of the world are located in this region; their 2017 throughput was the following: Shanghai, 40.2 million TEUs; Singapore, 33.7; Shenzhen, 25.2; Ningbo-Zhoushan, 24.6; Busan, 21.4; Hong Kong, 20.8; Guangzhou, 20.4.(source: UNCTAD [20] p. 73, tab. 4.4). A part from Singapore and Busan, all these ports are Chinese. The total DWT of the ships directed to South-East Asia/Far East from Italian ports is around 6.9 million tons (tab.4), while the average DWT of the ships is 133,030 tons. Along the DSS route between Mediterranean and Far East, the biggest ships operate. The Red Sea and Arabian/Persian Gulf are along this route. The most important port of Red Sea used to be Jeddah, but now it is the new port of King Abdullah (close to Jeddah), while the main port in the Arabian Gulf is Jebel Alì (the port of Dubai).

Some routes directed to Australasia cross ports of Red Sea and South-East Asia (especially Singapore) but the majority of routes to Australasia cross instead two east African ports: Pointe Des Galets and Port Louis.

In the American continent, the most important region, as far as routes from Italian ports are concerned, is Central America (Atlantic coast), both concerning the number of services and the total DWT: but it must be underlined that this world region (according to the classification of 'L'Avvisatore Marittimo') comprises some important U.S. ports, namely: Miami, Houston and New Orleans. In addition, Central America (Atlantic) comprises the two ports located on the Atlantic and Pacific side of the Panama Channel, i.e., respectively, Colòn and Balboa. North America (Atlantic coast) comprises important
U.S. and Canadian ports, such as Charleston, Norfolk, New York and Montreal. America/Pacific comprises the Canadian port of Vancouver, the U.S. ports of Los Angeles and Long Beach, and the Mexican port of Manzanillo.

\subsection{Comparison of DSS container routes in 2019 with those in 2011, 2014 and 2018 / Usporedba prekooceanskih $i$ kontejnerskih ruta u 2019. s onima iz 2011., 2014. i 2018.}

In table 5, the evolution of DSS services, departing from Italian ports, is shown. On the average, along the time period considered, the number of services per month has decreased, but the total DWT has increased. In particular the average DWT has constantly increased, which clearly shows the development of the naval gigantism phenomenon in container ships. This trend is shown specifically by Ligurian gateway ports: from 2011 to 2019 the number of services per month has decreased by $14 \%$, but the total DWT has increased by over $46 \%$ and the average DWT by $70.6 \%$.

As far as the Italian Northern Adriatic ports is concerned: the number of services per month has decreased from 9 to 7, from 2011 to 2019, but the total DWT has increased by $120.7 \%$ and the average DWT by $183.7 \%$ (the increase of Italian northern Adriatic ports is almost exclusively due to Trieste). However, currently, the number of DSS services departing from these ports is very low: this situation could change with the development of the economic markets of Central-Eastern Europe. In any case, it must be underlined that the non Italian port of Koper (Slovenia) is the main port in the Northern Adriatic gateway system. It has recorded 12 DSS services per month in 2018, all of them directed to Far East.

Campanian gateway ports have instead shown a negative trend: the number of services per month has decreased by almost $50 \%$, and the total DWT by $45 \%$; the average DWT has slightly increased, by $7.5 \%$. This negative trend is due to the decrease of traffic in the port of Naples, which is only partially compensated by the increase of traffic in the port of Salerno.

The most negative trend in Italy is shown by hub ports: currently, two of the three Italian hub ports, namely Cagliari and Taranto, are no longer crossed by DSS services. However, while only a few DSS services per month departed from Taranto (3 in 2011 and 5 in 2014), Cagliari was much more important: in 201124 DSS services departed from Cagliari and it recorded 
Table $5 \mathrm{~N}^{\circ}$ of services per month, total and average DWT for DSS routes from Italian ports, comparison among: 2011, 2014,2018 and 2019 Tablica 5. Broj usluga mjesečno, ukupna i prosječna bruto registarska tonaža za prekooceanske rute iz talijanskih luka, usporedba godina 2011. 2014., 2018.i 2019 .

\begin{tabular}{|c|c|c|c|c|c|c|c|c|c|c|c|c|}
\hline & \multicolumn{4}{|c|}{$\begin{array}{l}\mathrm{n}^{\circ} \text { services } \\
\text { per month }\end{array}$} & \multicolumn{4}{|c|}{$\begin{array}{c}\text { Total DWT } \\
\text { (thousand tons) }\end{array}$} & \multicolumn{4}{|c|}{$\begin{array}{l}\text { Average DWT } \\
\text { (thousand tons) }\end{array}$} \\
\hline & 2011 & 2014 & 2018 & 2019 & 2011 & 2014 & 2018 & 2019 & 2011 & 2014 & 2018 & 2019 \\
\hline Genoa & 80 & 80 & 94 & 81 & 4005.7 & 5408.7 & 7763.6 & 7972.5 & 50.1 & 67.6 & 82.6 & 98.4 \\
\hline La Spezia & 43 & 48 & 40 & 43 & 2572.4 & 3663.2 & 4509.9 & 4252.0 & 59.8 & 76.3 & 112.8 & 98.9 \\
\hline Leghorn & 40 & 40 & 46 & 41 & 1468.5 & 2089.7 & 2910.3 & 2760.2 & 36.7 & 52.2 & 63.3 & 67.3 \\
\hline Vado Ligure & 10 & 3 & 3 & 5 & 277.4 & 68.9 & 90.6 & 172.9 & 27.7 & 23.0 & 30.2 & 34.6 \\
\hline Total Ligurian gateway & 120 & 122 & 117 & 103 & 6118.0 & 8131.4 & 10041.8 & 8956.3 & 51.0 & 66.7 & 85.8 & 87.0 \\
\hline Ravenna & 2 & 0 & 0 & 0 & 23.8 & 0.0 & 0.0 & 0.0 & 11.9 & 0.0 & 0.0 & 0.0 \\
\hline Venice & 6 & 0 & 6 & 1 & 270.2 & 0.0 & 387.4 & 63.1 & 45.1 & 0.0 & 64.6 & 63.1 \\
\hline Trieste & 6 & 11 & 5 & 7 & 369.6 & 693.6 & 437.1 & 1011.0 & 61.6 & 63.1 & 87.4 & 144.4 \\
\hline Total northern Adriatic gateway & 9 & 11 & 7 & 7 & 458.1 & 618.6 & 528.4 & 1011.0 & 50.9 & 56.2 & 75.5 & 144.4 \\
\hline Naples & 35 & 16 & 17 & 14 & 1949.0 & 1101.5 & 1201.2 & 933.0 & 55.7 & 68.9 & 70.7 & 66.7 \\
\hline Salerno & 8 & 12 & 18 & 13 & 220.9 & 519.9 & 850.7 & 502.2 & 27.6 & 43.3 & 47.3 & 38.6 \\
\hline Total Campanian gateway & 43 & 27 & 30 & 22 & 2170.0 & 1583.5 & 1888.6 & 1195.3 & 50.5 & 58.7 & 63.0 & 54.3 \\
\hline Gioia Tauro & 32 & 37 & 34 & 27 & 2242.6 & 3325.1 & 3681.1 & 3006.6 & 70.1 & 89.9 & 108.3 & 111.4 \\
\hline Cagliari & 24 & 15 & 12 & 0 & 1130.9 & 1022.1 & 685.7 & 0.0 & 47.1 & 68.2 & 57.2 & 0.0 \\
\hline Taranto & 3 & 5 & 0 & 0 & 235.1 & 328.5 & 0.0 & 0.0 & 78.4 & 65.7 & 0.0 & 0.0 \\
\hline Total hub ports & 59 & 57 & 51 & 27 & 3608.6 & 4675.7 & 4569.7 & 3006.6 & 61.2 & 82.0 & 89.6 & 111.4 \\
\hline Civitavecchia & 0 & 0 & 9 & 7 & 0.0 & 0.0 & 600.7 & 284.7 & 0.0 & 0.0 & 66.8 & 40.7 \\
\hline Bari & 0 & 0 & 2 & 0 & 0.0 & 0.0 & 94.8 & 0.0 & 0.0 & 0.0 & 47.4 & 0.0 \\
\hline Catania & 0 & 0 & 2 & 0 & 0.0 & 0.0 & 27.9 & 0.0 & 0.0 & 0.0 & 13.9 & 0.0 \\
\hline Palermo & 0 & 0 & 0 & 1 & 0.0 & 0.0 & 0.0 & 44.6 & 0.0 & 0.0 & 0.0 & 44.6 \\
\hline Total other ports & 0 & 0 & 11 & 8 & 0.0 & 0.0 & 681.5 & 329.3 & 0.0 & 0.0 & 62.0 & 41.2 \\
\hline TOTAL ITALY & 150 & 158 & 132 & 121 & 8073.0 & 11281.7 & 11075.1 & 11683.2 & 53.4 & 71.4 & 83.9 & 96.6 \\
\hline
\end{tabular}

Sources: Lupi et al. [16],[17],[18], L'Avvisatore Marittimo [13], Marinetraffic [15] and shipping companies websites [19].

a total DWT of 1.1 million tons. As regards Gioia Tauro, from 2011 to 2019, the number of services per month departing from this port has decreased from 32 to 27 , while the total DWT has increased by $34 \%$ and the average DWT by almost $60 \%$. But it must be underlined that Gioia Tauro in 2011 was already in crisis, and it had already experienced a significant decrease in traffic from 2010 to 2011.

Finally, a few other Italian ports have registered some DSS services in 2018 and 2019: these have been classified as 'other ports' in table 5 . The most important port of this group is Civitavecchia, from which 9 and 7 DSS ships departed, respectively, in 2018 and 2019; from the other ports, i.e. Bari, Catania and Palermo, departed a maximum of 1-2 services per month.

As regards world regions, South-East Asia / Far East is by far the most important: see tab. 6. Actually this world region has shown a consistent decrease in the number of services per month from 2011 to 2019: by over 32\%; however, both the total and the average DWT have increased, respectively by $36.1 \%$ and by $101.5 \%$, which, again, clearly shows the development of the naval gigantism in maritime container services. Towards this region the biggest ships are directed: the average DWT in 2019 has been equal to 133,000 tons.

Other important world regions are Red Sea and Arabian/ Persian Gulf, which are located on the way to Far East. But some routes do not perform any intermediate stop from Suez Canal to South-East Asia / Far East; other routes arrive at Red Sea and Arabian/ Persian Gulf ports and do not continue to Far East; finally, some routes cross Red Sea, Arabian/ Persian Gulf, and end at Indian ports (often Nhava Sheva and Mundra, the main Indian ports, both located on the west coast of India).
The Red Sea World region, apparently, from tab. 6 shows a severe decrease of services from 2011 to 2014. These is due to the fact that, in 2011 analysis (Lupi et al. [18]), Suez, which is located on the south side of the Suez Canal, was considered as part of the Red Sea region and consequently a route reaching Suez was considered a DSS one. In the subsequent analysis $(2014,2018,2019)$ Suez has been considered as a Mediterranean port and consequently a route reaching Suez (and which did not continue beyond) was considered a SSS one.

As regards the American regions, North America (Atlantic) has only shown an increase in the average DWT: from 2011 to 2019 , the number of services per month directed to this region has decreased from 32 to 26 , while the total DWT has increased only by $5.6 \%$. Instead, Central America (Atlantic) has shown a slight decrease in the number of services per month, but the total DWT has increased by almost $70 \%$ and the average DWT by $85 \%$. This has occurred because in 2011 and 2014 the U.S. ports most connected to Italy were New York, Norfolk, Savannah and Charleston, which belong to North America Atlantic Coast region. Instead in 2018 and 2019 they were Miami, Houston and New Orleans, which belong to Central America region according to the classification of 'L'Avvisatore Marittimo' (but they are U.S. ports).

South America (according to the classification of 'L'Avvisatore Marittimo') comprises the Atlantic ports of Brazil, Argentina and Uruguay, and the Pacific port of Guayaquil (Ecuador). South America has shown a sharp increase, not only in the average DWT (+78\%) but also in the total DWT (+231\%) and in the number of services per month (+86\%). But it must be underlined that in 2011 only 7 ships per month were directed to ports of this region. 
Table $6 \mathrm{~N}^{\circ}$ of services per month, and total and average DWT for DSS routes from Italian ports, to each world region; comparison among: 2011, 2014, 2018 and 2019

Tablica 6. Broj usluga mjesecno, ukupna i prosječna bruto registarska tonaža za prekooceanske rute iz talijanskih gradova po pojedinim regijama, usporedba godina 2011., 2014., 2018. i 2019.

\begin{tabular}{|c|c|c|c|c|c|c|c|c|c|c|c|c|}
\hline \multirow[b]{2}{*}{$\mathrm{T}$} & \multicolumn{4}{|c|}{$\begin{array}{l}\mathrm{n}^{\circ} \text { services } \\
\text { per month }\end{array}$} & \multicolumn{4}{|c|}{$\begin{array}{c}\text { Total DWT } \\
\text { (thousand tons) }\end{array}$} & \multicolumn{4}{|c|}{$\begin{array}{l}\text { Average DWT } \\
\text { (thousand tons) }\end{array}$} \\
\hline & 2011 & 2014 & 2018 & 2019 & 2011 & 2014 & 2018 & 2019 & 2011 & 2014 & 2018 & 2019 \\
\hline West Africa & 8 & 10 & 10 & 5 & 201.7 & 364.3 & 376.0 & 213.6 & 25.2 & 36.4 & 37.6 & 42.7 \\
\hline Red Sea & 68 & 34 & 35 & 31 & 4372.4 & 2756.3 & 3657.5 & 3172.8 & 64.3 & 81.1 & 104.5 & 102.4 \\
\hline East / South Africa & 5 & 5 & 8 & 7 & 277.0 & 303.9 & 535.2 & 567.5 & 55.4 & 60.8 & 66.9 & 81.1 \\
\hline North America & 32 & 38 & 28 & 26 & 1577.6 & 2033.8 & 1937.1 & 1665.7 & 49.3 & 53.5 & 69.2 & 64.1 \\
\hline Central America & 33 & 26 & 38 & 30 & 1290.3 & 1237.6 & 2331.4 & 2174.9 & 39.1 & 47.6 & 61.4 & 72.5 \\
\hline South America & 7 & 19 & 9 & 13 & 413.0 & 953.8 & 886.9 & 1365.7 & 59.0 & 50.2 & 98.5 & 105.1 \\
\hline America / Pacific & 20 & 23 & 11 & 13 & 752.0 & 1667.5 & 932.1 & 781.6 & 37.6 & 72.5 & 84.7 & 60.1 \\
\hline Arabian / Persian Gulf & 35 & 26 & 27 & 37 & 2422.0 & 2247.2 & 2921.4 & 4548.9 & 69.2 & 86.4 & 108.2 & 122.9 \\
\hline South-East Asia / Far East & 77 & 66 & 49 & 52 & 5082.0 & 5884.1 & 5321.4 & 6917.6 & 66.0 & 89.2 & 108.6 & 133.0 \\
\hline Australasia / Pacific & 11 & 10 & 10 & 5 & 445.5 & 628.6 & 843.2 & 400.3 & 40.5 & 62.9 & 84.3 & 80.07 \\
\hline TOTAL & 150 & 158 & 132 & 121 & 8073.0 & 11281.7 & 11075.1 & 11683.2 & 53.8 & 71.4 & 83.9 & 96.6 \\
\hline
\end{tabular}

Sources: Lupi et al. [16],[17],[18], L'Avvisatore Marittimo [13], Marinetraffic [15] and shipping companies websites [19].

As far as America/Pacific (north and central America) is concerned, this region has shown a decrease in services from 2014 to 2018. This is due to the fact that the port of Balboa, located on the Pacific coast, on the west side of the Panama Channel, in 2011 and 2014 was considered part of America/Pacific, by 'L'Avvisatore Marittimo', while in 2018 and 2019 it was considered part of Central America (Atlantic). Some routes call at ports of Mexican Gulf, then cross the Panama channel, reach Balboa and return back to the Mexican Gulf: these routes in 2011 and 2014 were counted in both Central America (Atlantic) and America/ Pacific, while in 2018 and 2019 they were counted only in Central America (Atlantic). From 2018 to 2019 a slight increase in the number of services, directed to America/Pacific, has occurred, as well as a decrease in the average DWT (and in the total DWT). Indeed, in 2019 some new routes have been established, which cross the Panama Channel, call at Puerto Quetzal (Guatemala, Pacific coast) and Manzanillo (Mexico, Pacific coast), then return back to Panama: these routes are operated by small ships, much smaller than those which continue to Long Beach and Vancouver.

West Africa and East/South Africa are world regions with a reduced number of services. However, also for these regions it can be clearly observed, in the comparison between 2011 and 2019 data, the naval gigantism phenomenon.

As far as Australasia / Pacific is concerned, the number of services directed to this region has decreased, especially from 2018 to 2019, but, also in this case, the naval gigantism phenomenon, in the comparison between 2011 and 2019 data, can be observed.

\section{EVOLUTION OF SSS CONTAINER ROUTES IN THE MEDITERRANEAN AND IN THE BLACK SEA / Evolucija obalnih kontejnerskih ruta na Mediteranu i u Crnome moru}

The European Commission [21] has identified two main SSS regions in Europe: a first region which includes the Mediterranean and Black Sea ports; a second region which includes ports located in the North Sea and Baltic Sea.

SSS container routes in the Mediterranean and in the Black Sea, departing from Italian ports, in 2018, are compared with those of 2010. Data have been collected: from May to July 2018, and in March 2010. Routes collected in 2018 are reported in Lupi et al. [22], while routes of 2010 are reported in Danesi et al. [23].

The evolution of SSS container routes is described in detail in Lupi et al. [22]. Herewith, only some synthetic remarks are provided.

From 2010 to 2018 , the number of routes departing from at least one Italian ports, has decreased, from 149 to $130(-12.8 \%)$, and the frequencies per month also decreased, from 542 to 493 (-9.0\%). However, routes have become longer: in $2018,63.8 \%$ of SSS routes cross more than 5 ports, while in 2010 such routes were only $50.3 \%$. Point-to-point routes, which were frequent in 2010 , in 2018 are only two: Naples - Piraeus and Ravenna - Piraeus, both feeder ones.

The number of SSS routes from each Italian port, in 2010 and 2018 , and their related frequencies, are shown in table 7 . In table 7, the row 'Italy' reports:

- the number of routes departing from at least one Italian port (i.e., taking into account all Italian ports as if they were a single port) in 2010 and 2018.

the overall frequency per month, of routes leaving at least one Italian port: 542 is the sum of the frequency per month of the 149 routes of the year 2010, while 493 is the sum of the frequencies per month of the 130 routes of the year 2018 .

From 2010 to 2018, the number of routes departing from at least one Italian port has decreased, as well as the frequencies per month. However, the majority of Italian ports, especially Ligurian ones, have recorded an increase in the number of routes and in the number of services per month: indeed the number of ports crossed by each route has considerably grown. The main Ligurian port is Genoa, which has shown a remarkable growth from 2010 to 2018 : by $49 \%$ in the number of SSS routes departing from this port, and by $65 \%$ in the frequencies per month.

As regards port clusters, instead, a general decrease of the number of routes crossing at least one port of the cluster and of the related frequencies per month can be observed. Only the Campanian cluster has increased the number of routes departing from at least one port of the cluster, and the related frequencies per month. This has occurred because SSS routes in 2018 cross a higher number of ports, and in particular they often cross more than one port of the same cluster. 
Table 7 Evolution of SSS routes, and related frequencies per month, departing from Italian ports in 2010 and 2018 In the row 'Italy' the number of routes leaving at least one Italian port and their overall frequency per month are reported.

Tablica 7. Evolucija obalnih ruta i odnosne učestalosti mjesečno koje kreću iz talijanskih ruta u 2010. i 2018. U retku "Italija" prikazan je broj ruta koje kreću iz najmanje jedne talijanske luke i njihova ukupna frekvencija mjesečno.

\begin{tabular}{|c|c|c|c|c|c|c|}
\hline \multirow[t]{2}{*}{ Italian port } & \multicolumn{3}{|c|}{$\begin{array}{l}\mathrm{n}^{\circ} \text { of SSS routes from the } \\
\text { given port }\end{array}$} & \multicolumn{3}{|c|}{$\begin{array}{l}\text { SSS frequencies per month ( } n^{\circ} \text { services per } \\
\text { month) from the given port }\end{array}$} \\
\hline & 2010 & 2018 & $\%$ & 2010 & 2018 & $\%$ \\
\hline Genoa & 49 & 73 & 49.0 & 170 & 281 & 65.3 \\
\hline La Spezia & 32 & 41 & 28.1 & 128 & 169 & 32.0 \\
\hline Leghorn & 23 & 26 & 13.0 & 80 & 103 & 28.8 \\
\hline Vado Ligure & 3 & 6 & 100.0 & 10 & 24 & 140.0 \\
\hline Marina Carrara & 1 & 0 & -100.0 & 2 & 0 & -100.0 \\
\hline Total Ligurian gateway & 80 & 76 & -5.0 & 285 & 281 & -1.4 \\
\hline Ancona & 12 & 12 & 0.0 & 46 & 50 & 8.7 \\
\hline Ravenna & 14 & 14 & 0.0 & 56 & 59 & 5.4 \\
\hline Venice & 19 & 20 & 5.3 & 74 & 81 & 9.5 \\
\hline Trieste & 12 & 10 & -16.7 & 51 & 46 & -9.8 \\
\hline Monfalcone & 1 & 0 & -100.0 & 4 & 0 & -100.0 \\
\hline Total Adriatic gateway & 28 & 25 & -10.7 & 109 & 101 & -7.3 \\
\hline Naples & 18 & 15 & -16.7 & 54 & 59 & 9.3 \\
\hline Salerno & 21 & 28 & 33.3 & 65 & 104 & 60.0 \\
\hline Total Campanian gateway & 31 & 37 & 19.4 & 103 & 134 & 30.1 \\
\hline Gioia Tauro & 37 & 38 & 2.7 & 146 & 160 & 9.6 \\
\hline Cagliari & 22 & 26 & 18.2 & 85 & 103 & 21.2 \\
\hline Taranto & 7 & 0 & -100.0 & 24 & 0 & -100.0 \\
\hline Total hub ports & 61 & 54 & -11.5 & 235 & 210 & -10.6 \\
\hline Bari & 0 & 3 & 100.0 & 0 & 9 & 100.0 \\
\hline Catania & 3 & 5 & 66.7 & 12 & 20 & 66.7 \\
\hline Civitavecchia & 4 & 4 & 0.0 & 13 & 17 & 30.8 \\
\hline Palermo & 3 & 1 & -66.7 & 12 & 4 & -66.7 \\
\hline Trapani & 1 & 1 & 0.0 & 8 & 4 & -50.0 \\
\hline Total other ports & 9 & 10 & 11.1 & 32 & 40 & 25.0 \\
\hline Italy (at least 1 Italian port) & 149 & 130 & -12.8 & 542 & 493 & -9.0 \\
\hline
\end{tabular}

Sources: Lupi et al. [22] and Danesi et al. [23]

\section{A GLOBAL OVERVIEW OF FREQUENCIES OF DSS AND SSS SERVICES FROM ITALIAN PORTS / Globalni pregled učestalosti prekooceanskih i obalnih ruta iz talijanskih luka}

In this section, the relevance of each port in the global Italian container market is looked over. In order to do so, DSS and SSS services, departing from each port, and each port cluster, are taken into account simultaneously.

DSS data have been collected in 2011, 2014, 2018 and 2019; SSS data have been collected in 2010 and in 2018. Therefore, in order to examine simultaneously DSS and SSS routes, and compare the evolution of DSS and SSS routes, the following years have been taken into account: 2011 for DSS, 2010 for SSS, and 2018 for both. In table 8, the number of services per month of both DSS and SSS routes departing from Italian ports are reported.

The percentages reported in table 8 are calculated as follows:

- For each port: number of services per month departing from a given port, divided by the total number of services per month leaving at least one Italian port;

- For each port cluster: number of services per month departing from at least one port of the given cluster, divided by the total number of services per month leaving at least one Italian port.
For example, in 2011, the number of DSS services per month departing from at least one Ligurian port, is equal to $80 \%$ of DSS services per month leaving at least one Italian port. Again, in 2011, the number of DSS services per month departing from Genoa, is equal to $53.3 \%$ of DSS services per month leaving at least one Italian port.

Ligurian ports are by far the most important ones, both as regards DSS and SSS services, and their importance has increased in the last years.

As far as the DSS services are concerned, the number of services per month departing from at least one Ligurian port has been equal to $80 \%$ in 2011 and 89\% in 2018, of services per month leaving at least one Italian port. As far as SSS services are concerned, the number of services per month departing from at least one Ligurian port, has been equal to $53 \%$, in 2010 , and $57 \%$ in 2018 , of the services per month leaving at least one Italian port.

Genoa is the main Italian port and its importance has considerably grown in the last years. Indeed, in 2011, the number of DSS services per month departing from Genoa have been equal to about $53 \%$ of the DSS services per month departing from at least one Italian port; in 2018 they have been equal to over $71 \%$. In 2010 , the number of SSS services per month departing from Genoa has been equal to about $31 \%$ of the SSS services per month leaving at least one Italian port; in 2018 they have been equal to $57 \%$. 
Table 8 Importance of each Italian port and port cluster: DSS routes, 2011-2018, and SSS routes, 2010-2018. The percentages reported in the table are calculated as: number of services per month departing from a given port or port cluster, divided by the total number of services per month departing from at least one Italian port

Tablica 8. Važnost svake talijanske luke i lučkoga klastera: prekooceanske rute, 2011. - 2018., i obalne rute, 2010. - 2018. Postoci navedeni u tablici izračunati su kao: broj usluga mjesečno, polazeći od glavne luke ili lučkoga klastera, podijeljeno s ukupnim brojem usluga mjesečno pruženim u najmanje jednoj talijanskoj luci.

\begin{tabular}{|c|c|c|c|c|c|c|c|c|}
\hline \multirow[t]{2}{*}{ Italian port } & \multicolumn{4}{|c|}{$\begin{array}{l}n^{\circ} \text { of DSS services per month } \\
\text { from the given port or port } \\
\text { cluster }\end{array}$} & \multicolumn{4}{|c|}{$\begin{array}{c}\mathrm{n}^{\circ} \text { of SSS services per month } \\
\text { from the given port or port } \\
\text { cluster }\end{array}$} \\
\hline & \multicolumn{2}{|c|}{2011} & \multicolumn{2}{|c|}{2018} & \multicolumn{2}{|c|}{2010} & \multicolumn{2}{|c|}{2018} \\
\hline Genoa & 80 & $53.3 \%$ & 94 & $71.2 \%$ & 170 & $31.4 \%$ & 281 & $57.0 \%$ \\
\hline La Spezia & 43 & $28.7 \%$ & 40 & $30.3 \%$ & 128 & $23.6 \%$ & 169 & $34.3 \%$ \\
\hline Leghorn & 40 & $26.7 \%$ & 46 & $34.8 \%$ & 80 & $14.8 \%$ & 103 & $20.9 \%$ \\
\hline Vado Ligure & 10 & $6.7 \%$ & 3 & $2.3 \%$ & 10 & $1.8 \%$ & 24 & $4.9 \%$ \\
\hline Marina Carrara & 0 & $0.0 \%$ & 0 & $0.0 \%$ & 2 & $0.4 \%$ & 0 & $0.0 \%$ \\
\hline Total Ligurian gateway (at least 1 Ligurian port) & 120 & $80.0 \%$ & 117 & $88.6 \%$ & 285 & $52.6 \%$ & 281 & $57.0 \%$ \\
\hline Ancona & 0 & $0.0 \%$ & 0 & $0.0 \%$ & 46 & $8.5 \%$ & 50 & $10.1 \%$ \\
\hline Ravenna & 2 & $1.3 \%$ & 0 & $0.0 \%$ & 56 & $10.3 \%$ & 59 & $12.0 \%$ \\
\hline Venice & 6 & $4.0 \%$ & 6 & $4.5 \%$ & 74 & $13.7 \%$ & 81 & $16.4 \%$ \\
\hline Trieste & 6 & $4.0 \%$ & 5 & $3.8 \%$ & 51 & $9.4 \%$ & 46 & $9.3 \%$ \\
\hline Monfalcone & 0 & $0.0 \%$ & 0 & $0.0 \%$ & 4 & $0.7 \%$ & 0 & $0.0 \%$ \\
\hline Total Adriatic gateway (at least 1 Adriatic port) & 9 & $6.0 \%$ & 7 & $5.3 \%$ & 109 & $20.1 \%$ & 101 & $20.5 \%$ \\
\hline Naples & 35 & $23.3 \%$ & 17 & $12.9 \%$ & 54 & $10.0 \%$ & 59 & $12.0 \%$ \\
\hline Salerno & 8 & $5.3 \%$ & 18 & $13.6 \%$ & 65 & $12.0 \%$ & 104 & $21.1 \%$ \\
\hline Total Campanian gateway (at least 1 Campanian port) & 43 & $28.7 \%$ & 30 & $22.7 \%$ & 103 & $19.0 \%$ & 134 & $27.2 \%$ \\
\hline Gioia Tauro & 32 & $21.3 \%$ & 34 & $25.8 \%$ & 146 & $26.9 \%$ & 160 & $32.5 \%$ \\
\hline Cagliari & 24 & $16.0 \%$ & 12 & $9.1 \%$ & 85 & $15.7 \%$ & 103 & $20.9 \%$ \\
\hline Taranto & 3 & $2.0 \%$ & 0 & $0.0 \%$ & 24 & $4.4 \%$ & 0 & $0.0 \%$ \\
\hline Total hub ports (at least 1 hub port) & 59 & $39.3 \%$ & 51 & $38.6 \%$ & 235 & $43.4 \%$ & 210 & $42.6 \%$ \\
\hline Bari & 0 & $0.0 \%$ & 2 & $1.5 \%$ & 0 & $0.0 \%$ & 9 & $1.8 \%$ \\
\hline Catania & 0 & $0.0 \%$ & 2 & $1.5 \%$ & 12 & $2.2 \%$ & 20 & $4.1 \%$ \\
\hline Civitavecchia & 0 & $0.0 \%$ & 9 & $6.8 \%$ & 13 & $2.4 \%$ & 17 & $3.4 \%$ \\
\hline Palermo & 0 & $0.0 \%$ & 0 & $0.0 \%$ & 12 & $2.2 \%$ & 4 & $0.8 \%$ \\
\hline Trapani & 0 & $0.0 \%$ & 0 & $0.0 \%$ & 8 & $1.5 \%$ & 4 & $0.8 \%$ \\
\hline Total other ports (at least 1 other port) & 0 & $0.0 \%$ & 11 & $8.3 \%$ & 32 & $5.9 \%$ & 40 & $8.1 \%$ \\
\hline Italy (at least 1 Italian port) & 150 & $100 \%$ & 132 & $100 \%$ & 542 & $100 \%$ & 493 & $100 \%$ \\
\hline
\end{tabular}

Sources: Danesi et al. [23], Lupi et al. [16],[18],[22].

Italian Adriatic ports are crossed by a lower number of DSS services: the number of DSS services per month from at least one Adriatic port, has been equal to about $5 \%$ of the DSS services per month from at least one Italian port in 2018. But the number of SSS services per month from at least one Adriatic port, has been equal to about $20 \%$ of the SSS services per month from at least one Italian port in 2018. Italian Adriatic ports therefore are not very relevant as regards DSS services, but are crossed by several SSS ones. The SSS services leaving at least one Italian Adriatic port are 101 per month: 49 are feeder services, 45 are SSS services connecting only gateway ports, 7 concern parts of DSS routes. The feeder services had transshipment connections, in 2010, mainly in the ports of: Gioia Tauro, Cagliari, Taranto and Marsaxlokk. Instead, the feeder services have had transshipment connections, in 2018, mainly in the ports of: Gioia Tauro, Marsaxlokk, Piraeus and Port Said. It must be underlined that, as to DSS services, the non Italian port of Koper (Slovenia) is the main port in the Northern Adriatic gateway system. As to SSS services, in 2018, it has recorded 80 SSS services per month (of which 12 are part of DSS routes).

As far as hub ports are concerned, the number of DSS services per month departing from at least one hub port, are equal to about $39 \%$ of DSS services per month leaving at least one Italian port in 2018; the number of SSS services per month departing from at least one hub port, are equal to about $43 \%$ of SSS services per month leaving at least one Italian port in 2018. Several services departing from hub ports cross also Ligurian ones. These percentages have remained almost the same from 2011 to 2018 (DSS) and from 2010 to 2018 (SSS).

\section{CONCLUSIONS / Zaključci}

In this paper, an analysis on the evolution of Deep Sea Shipping (DSS) and Short Sea Shipping (SSS) container routes departing from Italian ports has been carried out.

Data of DSS services clearly show the evolution of the naval gigantism phenomenon: the number of DSS services per month remained roughly constant or has decreased, for nearly all Italian ports, but the total DWT and the average DWT has increased (particularly the average DWT). As to DSS, the most important port cluster is by far the Ligurian one and Genoa is by far the major Italian gateway port. Adriatic ports play a minor role (but the situation is different for SSS routes). Hub ports have shown a clear decrease in the frequency of DSS services.

As regards world regions connected to Italian ports by DSS routes, the most important one is South-East Asia / Far East. Other important world regions are those located 'on the way' from the Mediterranean to Far East: namely Red Sea and Arabian / Persian Gulf. Other major routes are those directed to the ports in North and Central America (Atlantic coast). 
As regards SSS routes, on one side the number of routes, leaving at least one Italian port, as well as the frequency per month of these routes, have decreased; but on the other side, for the majority of Italian ports, in particular for Genoa, the number of routes departing from the given port and the services per month have increased. This is due to the increasing number of ports crossed by each route. The choice, of increasing the number of ports crossed by each route, has been performed by container SSS companies in order to maximize the load factor of the ships by serving a larger number of markets. This has been carried out not only for lo-lo (container) SSS routes, but also for container DSS ones (low steaming phenomenon), and for ro-ro SSS services (Motorways of the Sea) (Lupi et al. [24]) in order to cope with the economic and financial crisis of 2008-2009.

Also as to SSS, the Ligurian gateway system is the major Italian port cluster and Genoa is the major Italian port. The north Adriatic gateway cluster is also important as regards SSS services, although, currently, much less than the Ligurian one. Instead, Italian hub ports have decreased both in the number of routes and in the number of services per month.

\section{REFERENCES / Literatura}

[1] Rodrigue, J. P. (2017). The Geography of Transport Systems. Fourth Edition. New York, US: Routledge.

[2] Notteboom, T., Rodrigue, J. P. (2005). "Port regionalization: towards a new phase in port development". Maritime Policy and Management, Vol. 32, No. 3, pp. 297-313. https://doi.org/10.1080/03088830500139885

[3] Monios, J., Wilmsmeier, G. (2013). "The role of intermodal transport in port regionalisation". Transport Policy, Vol. 30, pp. 161-172. https://doi. org/10.1016/j.tranpol.2013.09.010

[4] Lupi, M., Pratelli, A., Giachetti, A., Farina, A. (2018). "Rail freight transport in Italy: an analysis of combined transport connections/ll trasporto ferroviario in Italia: una analisi dei collegamenti ferroviari di trasporto combinato". Ingegneria Ferroviaria, Vol. 73, No. 3, pp. 209-245.

[5] Van Klink, H. A., Van Der Berg, G. C. (1998). "Gateways and intermodalism". Journal of Transport Geography, Vol. 6, No. 1, pp. 1-9. ISSN: 0966-6923. https://doi.org/10.1016/S0966-6923(97)00035-5

[6] Ferrari, C., Parola, F., Gattorna, E. (2011). "Measuring the quality of port hinterland accessibility: The Ligurian case". Transport Policy, Vol. 18, No. 2, pp. 382-391. ISSN: 0967-070X. https://doi.org/10.1016/j.tranpol.2010.11.002

[7] Baldassarra, A., Impastato, S., Ricci, S. (2010). "Intermodal terminal simulation for operations Management". European Transport/Trasporti Europei, Vol. 46, pp. 86-99. ISSN: 1825-3997.

[8] Notteboom, T. (2009). "Complementarity and substitutability among adjacent gateway ports". Environment and Planning A: Economy and Space, Vol. 41, No. 3, pp. 743-762. ISSN: 0308-518X. https://doi.org/10.1068/a40220

[9] Notteboom, T. (2010). "Concentration and the formation of multi-port gateway regions in the European container system: an update". Journal of Transport Geography, Vol. 18, No. 4, pp. 567-583. ISSN: 0966-6923. https:// doi.org/10.1016/j.jtrangeo.2010.03.003
[10] Buonfanti, A. (2013). "Lo shipping e la portualità nel Mediterraneo: opportunità e sfide per I'Italia". Proceedings of XV Conference of the Italian Association of Transport Economics and Logistics (SIET). Available at: http:// www.sietitalia.org/siet2013/PP/Buonfanti.pdf [accessed 12/2019]

[11] Assoporti: Statistiche annuali complessive. Available at: https://www. assoporti.it/it/autoritasistemaportuale/statistiche/statistiche-annualicomplessive/ [accessed 12/2019]

[12] Assoporti: Movimento contenitori in principali porti del Mediterraneo e de Mar Nero. Available at: https://www.assoporti.it/it/autoritasistemaportuale/ statistiche/statistiche-mondiali/movimento-contenitori-in-principaliporti-del-mediterraneo-e-del-mar-nero/ [accessed 12/2019]

[13] L'Avvisatore Marittimo. Editions of: March 2010, January 2011, March 2018, May 2018 and October 2019. II Secolo XIX editions, Genoa, Italy.

[14] II Messaggero Marittimo. Editions of July and August 2014. II Messaggero Marittimo editions, Livorno, Italy.

[15] Marinetraffic website. Available at: www.marinetraffic.com

[16] Lupi, M., Pratelli, A., Licandro, C., Farina, A. (2019). "The evolution of deep sea container routes: The Italian case". Transport Problems, Vol. 14, No. 1, pp. 69-80. ISSN: 1896-0596. DOI: 10.20858/tp.2019.14.1.7. https://doi. org/10.21307/tp.2019.14.1.7

[17] Lupi, M., Farina, A., Severi, F. (2015). "A comparison of deep sea container routes in the years 2011-2014". Proceedings of $17^{\text {th }}$ International Conference on Transport Science (ICTS) 2015, pp. 251-260.

[18] Lupi, M., Danesi, A., Farina, A., Pratelli, A. (2012). "Maritime container transport in Italy. Study on Deep and Short Sea Shipping routes departing from the main Italian ports, and on rail modal shares/ll trasporto marittimo di container in Italia. Studio sulle rotte Deep e Short Sea Shipping in partenza dai principali porti Italiani e sulle quote modali ferroviarie". Ingegneria Ferroviaria, Vol. 67, No. 5, pp. 409-444. ISSN: 0020-0956. https:// doi.org/10.21307/tp.2019.14.1.7

[19] Websites of deep sea shipping container operators. Available at: A. P. Moller-Maersk: https://www.maersk.com/schedules/\#vesselSchedules; CMA-CGM: https://www.cma-cgm.com/ebusiness/schedules/voyage; Cosco Shipping: https://elines.coscoshipping.com/ebusiness/sailingSchedule/sear chByVesselName; Evergreen Marine Corp.: https://www.shipmentlink.com/ tvs2/jsp/TVS2_VesselSchedule.jsp; Hapag-Lloyd: https://www.hapag-lloyd. com/en/online-business/schedules/vessel-tracing.html; OOCL: https://www. oocl.com/eng/ourservices/eservices/trackandtrace/Pages/default.aspx; Safmarine: https://www.safmarine.com/schedules/\#vesselSchedules; Yang Ming Marine Transport Corp.: https://www.yangming.com/service/service network/fleet.aspx; ZIM Integrated Shipping Services: https://www.zim.com/ schedules/schedule-by-vessel

[20] UNCTAD (United Nations Conference on Trade And Development) (2018) Review of Maritime Transport 2018, Geneva, Switzerland.

[21] European Commission (1999). The Development of Short Sea Shipping in Europe: A Dynamic alternative in a Sustainable Transport Chain. Second two-yearly progress report, Brussels, p. 39.

[22] Lupi, M., Pratelli, A., Falleni, M., Farina, A. (2019). "An analysis of short sea shipping container routes in the Mediterranean and in the Black Sea". WSEAS Transactions on Environment and Development, Vol. 15, pp. 120-138. ISSN: 1790-5079.

[23] Danesi, A., Farina, A., Lupi, M. (2010). "A comparative analysis of lo-lo and ro-ro Short Sea Shipping networks in Italy". Proceedings of $13^{\text {th }}$ International Conference on Transport Science (ICTS) 2010, pp. 1-11.

[24] Lupi, M., Farina, A., Pratelli, A., Bellucci, L. (2017). "An analysis of the Italian ro-ro and ro-pax network in the years 2008-2015". Transport Problems, Vol. 12, Special Edition, pp. 127-140. https://doi.org/10.20858/tp.2017.12.se.11 